\title{
Impact of Drop Jump Index For17-18 Year Old Volleyball Players in Albania
}

\author{
Enkeleida Lleshi ${ }^{1}$, Rigerta Selenica ${ }^{2}$,Altin Martiri ${ }^{3}$ \\ ${ }^{1}$ Department of Research in Applied Movement, Institute of Sport Research, Sports University of Tirana, ALBANIA \\ ${ }^{2}$ Department of Social Science and Education, Faculty of Movement Science, Sports University of Tirana, ALBANIA \\ ${ }^{3}$ Department of Sports, Faculty of Movement Science, Sports University of Tirana, ALBANIA
}

\begin{abstract}
Volleyball is characterized by the activity of vertical jump performance in the technical elements of attack, block and service. The study focuses on young Female \& Male players during the 12-week plyometric training. The objective of this study is to evaluate the effects of 12 -weeks plyometric training performance in volleyball players $\mathrm{M} \& \mathrm{~F}$ in Albania to see the differences between them. Methods; 40 young players (F \& M) participated in this study. N=10 M \& N=10 F volleyball players considered as Experimental and the same number as Control. The average age of players included in this study is 17-18 years old. The players of both groups were evaluated before and after 12 weeks. The F\&M Experimental groups conducted 12 weeks of plyometric training with 2 sessions for a week. The F\&M Control groups conducted the training according to the method of their trainers. Besides anthropometric measurements they developed Drop Jump tests by jumping from the cube in height $40 \mathrm{~cm}$ and 60 $\mathrm{cm}$. Results; The results showed a high correlation coefficient $(\mathrm{r}=0,924)$ and statistically significant $(\mathrm{p}<0,05)$. Data obtained from two groups GRFP show that the relationship between the contact time and the time air changes between the two tests DJ 40$60 \mathrm{~cm}$. Conclusions. The methodology used helps us compare the high and poor performances that help coaches to program more detailed plyometric training for the development of jumping skills in young volleyball players. The effect of plyometric training developed on M\&F volleyball players and according to data obtained from GRFP, showed that male volleyball players had a better performance in vertical jump than female volleyball players. Vertical jumping may be assessed not only by the height of its development but also by the phase of residence in the air.
\end{abstract}

Keywords

volleyball, drop jump, plyometric training, younger.

Article Received: 10 August 2020, Revised: 25 October 2020, Accepted: 18 November 2020

\section{Introduction}

Collective sports such as volleyball, football, etc., have different performances for their own characteristics of the game, so the training is specific where there are differences in the physical qualities of individuals and team performance. These sports have an important element in common "vertical jumping". A volleyball player during a game or a match alongside the technical elements - should develop tactical and technical elements such as; attack, block, service and/or following by vertical jumping. An important trend in modern volleyball is to increase the level of vertical jump. The best perfection of a vertical jump is achieved through certain training in order to increase the height of the jump. Some researchers have shown that jumps in height can be greatly improved through plyometric exercises. To assess the vertical jump, the application of Bosco tests is needed such as Drop Jump [Cometti $G$ et al, 2009] that made possible the definition of the height of the optimum fall from which the volleyball player takes $\backslash$ wins the maximum jumping and the connection between the height of the fall, the time of contact and flight-time. Some authors have reported [Voelzke M. et al, 2012] that commanded plyometric training shows that exercises are effective in increasing the jump, speed and skill of volleyball players. Plyometric is a form of resistance exercise that refers to the stretch-shortening cycle (SSC) such as jumps or doing vertical or horizontal jumps [Fleck, S. J.et al, 2004].Coaches need exercises that are less time consuming and help to improve the vertical jumping ability of their players. Training to increase jump height, according to previous studies, has been focused on the role of muscle strength trained through strength training methods [L.Fernando, et al, 1997]. Research has shown that the height of the vertical jump also depended on the elastic energy accumulated by the skeletal muscles through the force of the muscle-tendon bond influencing the onset of concentric movement in the occurrence of increased jump performance [Giovanni. A.et al, 1968; Heitler, W. J. et al, 1977; Yamazaki, Y.e al, 
1989]. From the research done it is essential to know when the most favorable period is to develop and improve vertical jump [Cometti .G et al, 2009], for men the period to evolve is one year after the peak of puberty and females after six months. It is therefore suggested that training programs be planned for these ages. Plyometric exercises use the stretch-shorten cycle to train the muscles to perform, and perform greater work in the shortest possible time [Holcomb William R. et al, 1996]. In plyometric motor activity, muscles move very fast from eccentric movement to concentric contraction, leaving no time for the muscle to rest. Realization of the lengtheningshortening cycle without rest time realizes the accumulation of elastic energy from the muscletendon connection by transmitting the generation by the muscle of a greater force [Holcomb William R. et al, 1996; Hoskins, M. et al, 2005]. This study is to evaluate the effects of 12-weeks plyometric training the same in volleyball players Male \& Female younger in Albania and to see the differences between them.

\section{Methodology}

Table 1 presents the average data of anthropometric measurements of volleyball players. In total there are 40 young men volleyball players from different clubs in Albania respectively with 10 players each group Female (F) \& Male (M). Group (F) was considered in the Experimental (EX) and Control (CO) groups and the same division for the male player groups. The average age of players included in this study is 1718 years old. All 40 F\&M volleyball players underwent anthropometric measurements; body height $(\mathrm{BH} \mathrm{cm})$, body weight (BW $\mathrm{kg}$ ), BMI $\mathrm{kg} / \mathrm{m}^{2}$.

Table.1: Anthropometric measurements.

\begin{tabular}{|c|c|c|c|c|}
\hline & \multicolumn{2}{|l|}{ M ALE } & \multicolumn{2}{|c|}{ FEMALE } \\
\hline & EX & $\mathrm{CO}$ & EX & $\mathrm{CO}$ \\
\hline & Nr.10 & Nr.10 & Nr.10 & Nr.10 \\
\hline AGE & $\begin{array}{ll}18 & \\
S D & 1.1\end{array}$ & $\begin{array}{l}17 \\
S D 0.9\end{array}$ & $\begin{array}{ll}17 & \\
S D & 1.6\end{array}$ & $\begin{array}{ll}18 & \\
S D & 0.8\end{array}$ \\
\hline $\begin{array}{l}\mathrm{BH} \\
\mathrm{cm}\end{array}$ & $\begin{array}{l}185.3 \\
S D 7.3\end{array}$ & $\begin{array}{l}187.9 \\
S D \quad 9.4\end{array}$ & $\begin{array}{l}173.7 \\
S D 4.9\end{array}$ & $\begin{array}{l}170.3 \\
S D \quad 3.8\end{array}$ \\
\hline $\begin{array}{l}\mathrm{BW} \\
\mathrm{kg}\end{array}$ & $\begin{array}{l}76.3 \\
S D 12.1\end{array}$ & $\begin{array}{l}70.2 \\
S D 10.0 \\
8\end{array}$ & $\begin{array}{l}62.06 \\
S D \quad 6.5\end{array}$ & $\begin{array}{l}62.5 \\
S D 2.6\end{array}$ \\
\hline $\begin{array}{l}\mathrm{BMI} \\
\mathrm{kg} / \mathrm{m} \\
2\end{array}$ & $\begin{array}{l}22.19 \\
S D 2.4\end{array}$ & $\begin{array}{l}20.37 \\
\text { SD } 2.06\end{array}$ & $\begin{array}{l}20.64 \\
S D \quad 2.08\end{array}$ & $\begin{array}{l}20.96 \\
S D \\
2.01\end{array}$ \\
\hline
\end{tabular}

\subsection{Experimental Procedure.}

The Plyometric training program without weight is implemented by the experimental groups F\&M volleyball players for 12 weeks and is held twice a week with duration of 90 minutes (MondayWednesday) and three other sessions of technicaltactical exercise with ball. Control Group has developed only 5 technical-tactical training sessions with the ball. Experimental Group in the implementation of the training program has developed only plyometric exercises and the level of the height of the vertical jump was defined adapted to DJ $40 \mathrm{~cm}$ and DJ $60 \mathrm{~cm}$ tests.

\subsection{Test protocol.}

The purpose of this test is to assess volleyball players F\&M the Time Air (TA) and Time Contact (TC) in DJ performance tests at two different heights $(40 \mathrm{~cm}$ and $60 \mathrm{~cm})$. In the beginning were conducted anthropometric measurements and later on the tests in vertical jump performance of the protocol tests. This test is performed on lab equipment platform Leonardo ${ }^{\circledR}$ system Ground Reaction Force Plate (GRFP) in University of Sports, Tirana. Volleyball players are placed in a row on the cube height $40-60 \mathrm{~cm}$, with their hands on their loins. Through a free fall from the height of the cube they leave themselves falling into GRFP platform and rapidly react after contacting GRFP by jumping as high as possible. The test has been developed 3 times and we got the best measure of the contact time and the time in the air.

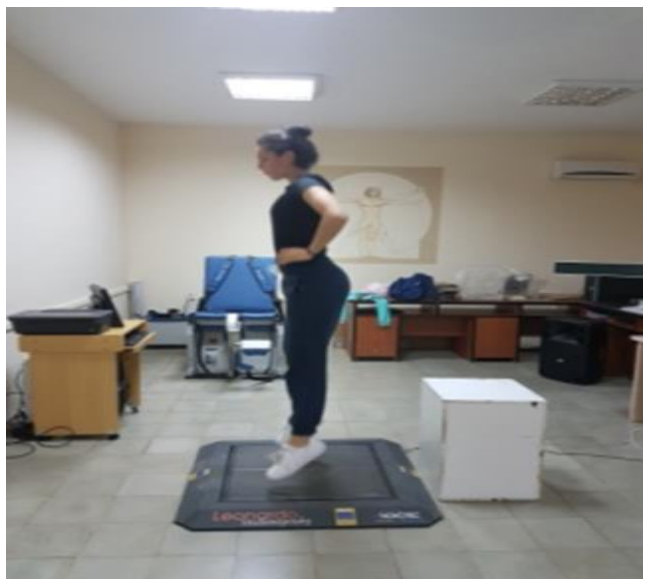




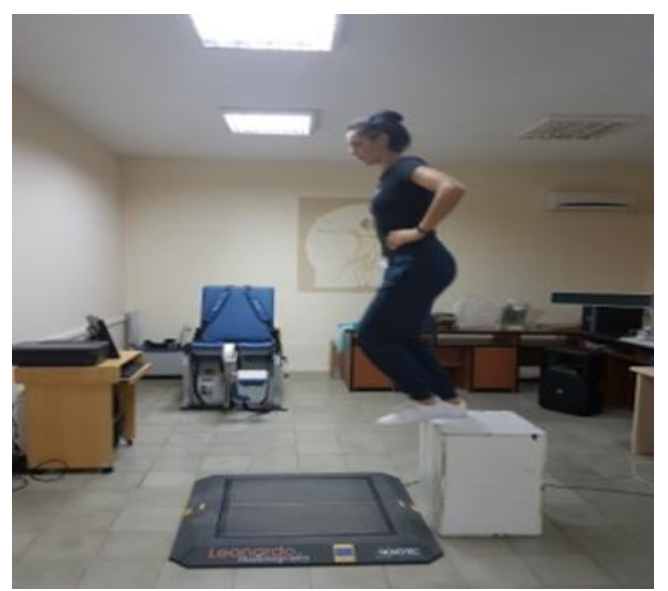

Fig.1. Drop Jump Test by volleyball players

\subsection{Intervention in experimental groups.}

The program developed for F\&M experimental groups includes intensive application loads such as horizontal jumps to obstacle jumps and deep

Table.2. Plyometric training 1-12 week

\begin{tabular}{|c|c|c|c|c|c|}
\hline $\begin{array}{l}\text { Wee } \\
\mathrm{k}\end{array}$ & EXERCISES & Frequent & $\begin{array}{l}\text { Time } \\
\text { Extension } \\
\text { Action }\end{array}$ & $\begin{array}{l}\text { Volum } \\
\text { e } \\
\text { Load } \\
\text { Basic } \\
\end{array}$ & $\begin{array}{l}\text { Total } \\
\text { Week } \\
\text { Jump }\end{array}$ \\
\hline 1 & $\begin{array}{l}\text { Indian Zinc jumps, Side jumps on the } 1 \text {-foot } \\
(20 \mathrm{~cm}) \text {.Jumping over obstacles with } 2 \text { legs } \\
(40 \mathrm{~cm})\end{array}$ & $2 \mathrm{x}$ week & $\begin{array}{l}\text { Many } \\
\text { quickly }\end{array}$ & $2 \times 10$ & 188 \\
\hline $2,3,4$ & $\begin{array}{l}\text { Jumps up \& down, Drop-jumps } 2 \text { feet } 40 \mathrm{~cm} \\
\text {,Jumping over obstacles } 2 \text { feet }(60 \mathrm{~cm})\end{array}$ & $2 \mathrm{x}$ week & $\begin{array}{l}\text { Many } \\
\text { quickly }\end{array}$ & $\begin{array}{l}2 \times 10 \\
3 \times 10\end{array}$ & 148 \\
\hline 5 & $\begin{array}{l}\text { VJ with the support of one foot, Zinc jump (2 } \\
+2)(6+6) \text {, Jumping over obstacles with } 2 \\
\text { legs }(40 \mathrm{~cm})\end{array}$ & $2 \mathrm{x}$ week & $\begin{array}{l}\text { Many } \\
\text { quickly }\end{array}$ & $\begin{array}{l}3 \times 12 \\
2 \times 12\end{array}$ & 168 \\
\hline $6,7,8$ & $\begin{array}{l}\text { Jumps up \& down over } 1 \text { foot, VJ from the } \\
\text { obstacle crossing drop }(40-60 \mathrm{~cm}) \text { Jumping } \\
\text { over obstacles } 2 \text { feet with contrast in height } \\
(40-60 \mathrm{~cm})\end{array}$ & $2 \mathrm{x}$ week & $\begin{array}{l}\text { Many } \\
\text { quickly }\end{array}$ & $\begin{array}{l}2 \times 8 \\
3 \times 12 \\
3 \times 10\end{array}$ & 180 \\
\hline 9,10 & $\begin{array}{l}\text { Jumps up \& down, DJ from the object } 40 \mathrm{~cm} \\
\text { high touch } \\
\text { Jumping from the object }(60 \mathrm{~cm}) \text { touching at } \\
\text { height }\end{array}$ & $2 \mathrm{x}$ week & $\begin{array}{l}\text { Many } \\
\text { quickly }\end{array}$ & $\begin{array}{l}2 \times 8 \\
3 \times 12\end{array}$ & 180 \\
\hline $\begin{array}{l}11,1 \\
2\end{array}$ & $\begin{array}{l}\text { Jumps up \& down, Side jumps over } 1 \text {-foot } \\
\text { hurdle }(20 \mathrm{~cm}) \text { Falling jumps from the object } \\
\text { with } 1 \text { foot }(40 \mathrm{~cm}) \text { touch in height } \\
\text { Jumping from the object } 40 \mathrm{~cm}) \text { touch at } \\
\text { height }\end{array}$ & $2 \mathrm{x}$ week & $\begin{array}{l}\text { Many } \\
\text { quickly }\end{array}$ & $\begin{array}{l}2 \times 8 \\
2 \times 12 \\
3 \times 12\end{array}$ & 192 \\
\hline
\end{tabular}

\subsection{Instruments.}

The Leonardo ${ }^{\circledR}$ Ground Force Reaction Plate (GRFP-Novotec Medical, Pforzheim, Germany) contact platform was used to evaluate the Drop Jump test in the volleyball players studied. DJ40 cm and DJ60cm tests have been developed jumps. Exercises performed with one leg have the highest intensity. Intensity escalation is used not only within a training session but also from week to week. Another component that increases the intensity of the training load is the use of heights of objects or tools, which comes according to the principle of progressivity where at first the jumps are given only with detachment from the ground and gradually increase the height of the vehicle [Knak Jensen. et al,2017; E.Stojanović, V. et al, 2017 ]. Plyometric training has been shown to be beneficial in improving vertical jump performance in volleyball. Table 2 shows the training of experimental groups of female \& male volleyball players. on this platform. This GRFP platform is located in the premises of the Biomechanics Laboratory at the University of Sports of Tirana (UST). GRFP was used _ BEFORE and _ AFTER the 12-week training program of the volleyball players participating in this study to develop these tests. The volleyball players were instructed that they 
should conduct jump testing at their maximum possible performance.

\section{Statistical analysis.}

The data is collected and processed in an Excel spreadsheet. They transferred the analysis by using the SPSS statistical package (Windows version). The aim consisted in identifying any possible change as a training effect. ANOVA analysis with 2 repeated measurements for maximum Force as a dependent variable and (Experimental / Control group) as independent resulted in statistically non-significant values $(\mathrm{p}$ $<0,05)$ for Drop Jump 40cm and for Drop Jump $60 \mathrm{~cm}$. ANOVA analysis with 2 repeated measurements for maximum Power as dependent variable and (experimental/control) group as independent resulted in statistically nonsignificant values $(\mathrm{p}<0,05)$ for DJ $40 \mathrm{~cm}$ and for DJ $60 \mathrm{~cm}$.

\section{Results}

The results shown in tab. 3 of $D J 60 \mathrm{~cm}$ and DJ40 cm tests' performance differ from each other. The variables of force and power were tested for statistically significant differences between the experimental and control groups. The reliability of tests is controlled by the "test-retest" method, as one of the most used ways in similar tests, as to minimize the effect of other factors that are not taken into account in the study. The main objective consisted in testing the sustainability of the results. According to the data obtained from GRFP of F\&M volleyball players, which we have presented in tab.3 and fig.1, show that the results of descriptive statistical analysis for the dependent variable "TA / TC" showed that there is a progress in growth of the dance performance in this test in both groups after following the plyometric training plan.

Table.3. Descriptive statistics for DJ40-60 test at Pre \& Post

\begin{tabular}{|c|c|c|c|c|c|}
\hline $\begin{array}{l}\text { Female } \\
\text { DJ40 }\end{array}$ & $\begin{array}{l}\text { Fmax } \\
\text { Pre_- } \\
\text { Post_ }\end{array}$ & $\begin{array}{l}\text { Pmax } \\
\text { Pre_- } \\
\text { Post_ }\end{array}$ & $\begin{array}{l}\text { Time Contact } \\
\text { Pre_ } \\
\text { Post_ }\end{array}$ & $\begin{array}{l}\text { Time Air } \\
\text { Pre_- } \\
\text { Post_ }\end{array}$ & $\begin{array}{l}\text { TA/TC } \\
\text { Pre_ } \\
\text { Post_ }\end{array}$ \\
\hline $\mathrm{EX}$ & $\begin{array}{l}2.57 \\
2.37 \\
\end{array}$ & $\begin{array}{l}24.85 \\
25.86\end{array}$ & $\begin{array}{l}0.358 \\
0.376\end{array}$ & $\begin{array}{l}0.448 \\
0.463\end{array}$ & $\begin{array}{l}1.28 \\
1.36\end{array}$ \\
\hline $\mathrm{CO}$ & $\begin{array}{l}2.54 \\
2.22 \\
\end{array}$ & $\begin{array}{l}22.8 \\
23.06 \\
\end{array}$ & $\begin{array}{l}0.302 \\
0.323 \\
\end{array}$ & $\begin{array}{l}0.423 \\
0.431 \\
\end{array}$ & $\begin{array}{l}1.2 \\
1.25 \\
\end{array}$ \\
\hline $\begin{array}{l}\text { Male } \\
\text { DJ40 }\end{array}$ & $\begin{array}{l}\text { Fmax } \\
\text { Pre_- } \\
\text { Post_ }\end{array}$ & $\begin{array}{l}\text { Pmax } \\
\text { Pre_- } \\
\text { Post_ }\end{array}$ & $\begin{array}{l}\text { Time Contact } \\
\text { Pre_ } \\
\text { Post_ }\end{array}$ & $\begin{array}{l}\text { Time Air } \\
\text { Pre_- } \\
\text { Post_ }\end{array}$ & $\begin{array}{l}\text { TA/TC } \\
\text { Pre_ } \\
\text { Post_ }\end{array}$ \\
\hline $\mathrm{EX}$ & $\begin{array}{l}2.5 \\
2.54 \\
\end{array}$ & $\begin{array}{l}33.69 \\
30.07 \\
\end{array}$ & $\begin{array}{l}0.376 \\
0.397 \\
\end{array}$ & $\begin{array}{l}0.553 \\
0.519 \\
\end{array}$ & $\begin{array}{l}1.25 \\
1.77 \\
\end{array}$ \\
\hline $\mathrm{CO}$ & $\begin{array}{l}2.44 \\
2.81\end{array}$ & $\begin{array}{l}27.05 \\
39.43\end{array}$ & $\begin{array}{l}0.419 \\
0.337\end{array}$ & $\begin{array}{l}0.499 \\
0.587\end{array}$ & $\begin{array}{l}1.4 \\
1.53\end{array}$ \\
\hline $\begin{array}{l}\text { Female } \\
\text { DJ60 }\end{array}$ & $\begin{array}{l}\text { Fmax } \\
\text { Pre_ } \\
\text { Post_ }\end{array}$ & $\begin{array}{l}\text { Pmax } \\
\text { Pre_- } \\
\text { Post_ }\end{array}$ & $\begin{array}{l}\text { Time Contact } \\
\text { Pre_ } \\
\text { Post_ }\end{array}$ & $\begin{array}{l}\text { Time Air } \\
\text { Pre_ } \\
\text { Post_ }\end{array}$ & $\begin{array}{l}\text { TA/TC } \\
\text { Pre_ } \\
\text { Post_ }\end{array}$ \\
\hline $\mathrm{EX}$ & $\begin{array}{l}3.19 \\
3.34\end{array}$ & $\begin{array}{l}23.32 \\
25.81\end{array}$ & $\begin{array}{l}0.362 \\
0.381\end{array}$ & $\begin{array}{l}0.422 \\
0.465\end{array}$ & $\begin{array}{l}1.55 \\
1.71\end{array}$ \\
\hline $\mathrm{CO}$ & $\begin{array}{l}3.16 \\
3.21\end{array}$ & $\begin{array}{l}34.02 \\
34.1\end{array}$ & $\begin{array}{l}0.362 \\
0.378\end{array}$ & $\begin{array}{l}0.411 \\
0.425\end{array}$ & $\begin{array}{l}1.53 \\
1.6\end{array}$ \\
\hline $\begin{array}{l}\text { Male } \\
\text { DJ60 }\end{array}$ & $\begin{array}{l}\text { Fmax } \\
\text { Pre_- } \\
\text { Post_ }\end{array}$ & $\begin{array}{l}\text { Pmax } \\
\text { Pre_- } \\
\text { Post_ }\end{array}$ & $\begin{array}{l}\text { Time Contact } \\
\text { Pre_ } \\
\text { Post_ }\end{array}$ & $\begin{array}{l}\text { Time Air } \\
\text { Pre_- } \\
\text { Post_ }\end{array}$ & $\begin{array}{l}\text { TA/TC } \\
\text { Pre_- } \\
\text { Post_ }\end{array}$ \\
\hline $\mathrm{EX}$ & $\begin{array}{l}3.39 \\
3.62\end{array}$ & $\begin{array}{l}35.42 \\
31.2\end{array}$ & $\begin{array}{l}0.348 \\
0.356\end{array}$ & $\begin{array}{l}0.552 \\
0.514\end{array}$ & $\begin{array}{l}1.66 \\
1.88\end{array}$ \\
\hline $\mathrm{CO}$ & $\begin{array}{l}3.16 \\
3.21\end{array}$ & $\begin{array}{l}35.03 \\
35.93\end{array}$ & $\begin{array}{l}0.348 \\
0.322\end{array}$ & $\begin{array}{l}0.552 \\
0.609\end{array}$ & $\begin{array}{l}1.68 \\
1.72\end{array}$ \\
\hline
\end{tabular}




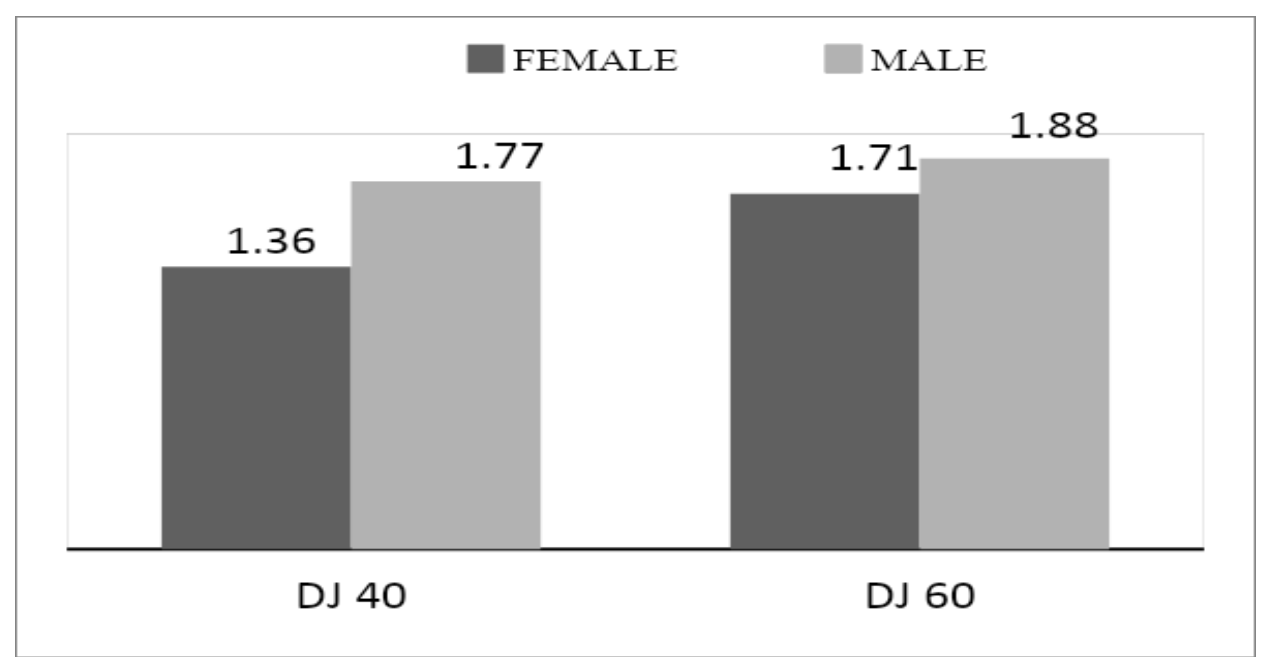

Fig.2.Drop Jump test at Post measurement.

In the measurement_Post plyometric training in the group of women there is an average increase of $0.8 \mathrm{sec}$ in the DJ $40 \mathrm{~cm}$ test. Experimental group noticed changes from (1.28-1.36) sec during the measurement__Pre the measurement_Post commanded plyometric training. Female control group in the measurement_Post (1.2-1.25) sec in the measurement_Post. The experimental group after plyometric training had a significant increase compared to the control group of $0.11 \mathrm{sec}$. While in the measurement_Post plyometric training in the male group there is an increase of $0.52 \mathrm{sec}$ on average in the DJ40 cm test. Experimental group noticed changes from (1.25-1.77) sec during the measurement _Pre the measurement_Post the commanded plyometric training. Male control group in the measurement _Before (1.4-1.53) sec in the measurement _Post. The experimental group after plyometric training had a significant increase compared to the control group of $0.24 \mathrm{sec}$. Drop Jump test $60 \mathrm{~cm}$ according to the obtained data showed that in the measurement _Post plyometric training in the male group there is an average increase of $0.16 \mathrm{sec}$. Experimental group noticed changes from (1.55-1.71) sec during the measurement. Female control group in the measurement_Pre (1.53-1.6) sec in the measurement_Post. The experimental group after plyometric training had a significant increase compared to the control group of $0.11 \mathrm{sec}$. Even the group of men in the Drop Jump 60cm test according to the data obtained showed that in the measurement_Post plyometric training there is an average increase of $0.22 \mathrm{sec}$. Experimental group noticed changes from (1.66-1.88) sec during the measurement command. Male control group in the measurement _Post (1.68-1.72) sec in the
measurement_Post. The experimental group after plyometric training had a significant increase compared to the control group of $0.16 \mathrm{sec}$.

\section{Discussion}

The linear correlation between "Drop Jump 40" and "Drop Jump 60" tests as an assessment would be intuitive and the connection that exists between the similarity jump -fall test from a height of 40 $\mathrm{cm}$ and one from $60 \mathrm{~cm}$. The correlation between the tests was measured according to the Pearson's moment product. The results showed a high correlation coefficient $(r=0,924)$ and statistically significant (sig. <0.05). The reliability of tests is controlled by the "test-retest" method, as one of the most used ways in similar tests, as to minimize the effect of other factors that are not taken into account in the study. It is held as an analysis to determine whether the test and measurement methods used were available to identify whether the volleyball groups did achieve high or poor performance. It was also analyzed whether the testing protocol was able to discern the changes coming from the 12-week plyometric training between the Experimental groups with that of the control Group. Results of force and power presented in tab 3 differ from each other. These differences make the interpretation more difficult for us because they do not provide the necessary results to observe the differences occurred during the plyometric training. Therefore, the maximum rate of force and power development, according to the test, is not considered a valid method to discern the changes after the training phase in volleyball groups. In this experiment the differences between the two groups were observed at the time of contact during the fall and the air 
time during the jump. The female experimental group after the programmed training of 12 weeks, showed in the test DJ $40 \mathrm{~cm}$ in the values of TA / TC an increase of $6.2 \%$ and in the test DJ $60 \mathrm{~cm}$ in the values of TA / TC in $10.3 \%$. While the experimental group of men after the programmed training showed that in the DJ $40 \mathrm{~cm}$ test the values were at $41.6 \%$ while in the DJ $60 \mathrm{~cm}$ test the TA / TC values were at $13.2 \%$. Moving tasks such as vertical jumps, hops, and / or bounding movements are used to increase the explosive ability and strength of the lower extremities as stated by the authors [Christopher.J. et al, 2005]. It is important to know the height identification especially in the application of fall jump tasks, the height which affects the benefit of vertical jump have been reported [Bobbert, MF.,et al, 1994; A Lees , et al, 1994; Walsh, et al, 2004]. This weekly cycle model recommended by us [Cometti G.et al ,2009] serves coaches and volleyball players to develop dance performance in two sessions per week. [Bosco ,C.et al, 1979] Komi \& Bosco compared the performance of vertical jumps in men \& women in three specific tests; SJ, CMJ and DJ where males performed higher than females but females had a good use of stored elastic energy. Plyometric training is widely used by trainers especially to educate and enhance neuromuscular functions in improving the performance of both explosive habits and motor endurance. It has been studied and shown that plyometric training develops neural factors and especially in the lengthening-shortening system of the muscle-tendon connection, to generate the greatest force expressed in the shortest possible time. This definition goes with the muscular strength reported by different authors [G.Markovic,et al, 2010]. We can say that the generation of force applied through plyometric exercises appears as force. Plyometric exercises are therefore used as the linking method of the force-velocity curve. Today it is one of the most used methods not only in the case of our study to increase jumping skills - jump height, but also widely used in increasing athletic performance in many different sport disciplines. [Komi, et al, 1978] They compared the performance of vertical jumps in males and females. These results show that practical experience suggests that in the training of volleyball players, with the use of Drop Jump exercises should be realized using a progression with lower and increasing volume, in a monitored state, so that the dance performance is realized in a way correct to also reduce the risk of injury that characterizes these types of activities.

\section{Conclusions}

Compared to the reference table in "Reactive Force Index Limit for Drop Jump Test" we say the level of athletes taken in the Experiment despite their improvement in the TA / TC Index score represent a level of moderate reactive force ability volleyball players prepared for moderate intensity plyometric and reactive force as the goal of performance enhancement. Based on the above conclusions we suggest increasing the jump height as necessary, increase the max strength indicators and increase the exercise intensity. The findings of this study show that the methodology used herein is accurate and helps to compare the great and poor performances that help coaches to program more detailed plyometric training for the development of jumping skills in young volleyball players. The effect of plyometric training developed on M\&F volleyball players and according to data obtained from GRFP, showed that male volleyball players had a better performance in vertical jump than female volleyball players. Vertical jump may be assessed not only by the height of its development but also by the phase of residence in air. The findings of this study show that the methodology used here is accurate and helps to compare high and poor performances which help coaches to program a weightless plyometric training to develop jumping ability in young volleyball players based on conditions that are located.

\section{Reference}

\section{[1] Voelzke M.Stutzig N.Thorhauer H.A.Urs.Granacher.(2012) Promoting lower extremity strength in elite volleyball players: effects of two combined training methods. Journal of Science and Medicine in Sport. Vol. 15(5): pp .457-462.}

[2] Cometti G., \& Cometti .D (2009), La Pliometria . Origini, teorie, allenamento. Allenamento Sportivp. Stampa ;Tipografia Mancini s.a.s(Tivoli),Calzetti Mariucci.pp60- 67, pp87118.

[3] Fleck, S. J., \& Kraemer, W. J.(2004)Advanced training strategies. Designing Resistance Training Programs Champaign, IL: Journal Human Kinetics.ISBN-10: 0-7360-8170-4 (print). 3rd ed., pp.209-239. 
[4] L.Fernando, A.Vargas., M.Gross.(1997). Kinesiological Factors in Vertical Jump Performance: Differences Among Individuals .Journal of Applied Biomechanics, Vol 13(1), pp. 24-44.

[5] Giovanni. A. Cavagna, B. Dusman,.\& R. Margaria(1968). Positive work done by a previously stretched muscle"?. Journal of Applied Physiology.Vol.No. 1.pp 21-27.

[6] Heitler, W. J. and Burrows, M.(1977). The locust jump, The motor programme. Journal Exp. Biol.pp.203-219.

[7] Yamazaki, Y., Suzuki. M., \& Mano, T. (1989). Performance of countermovement jump with both knee and hip joints fully extended. Journal of Applied Physiology. Vol.66(4). pp.1976 1983.

[8] Holcomb William R.; Lander, Jeffrey E.; Rutland, Rodney M.; Wilson, G. Dennis.(1996).Journal of Strength and Conditioning Research: pp. 89-92.

[9] Hoskins, M. Coleman \& D. McNeely.(2005). Stress in carers of individuals with dementia and Community Mental Health Teams: an uncontrolled evaluation study. Journal of Advanced Nursing. Vol. 50(3):pp.325-333.

[10] Knak Jensen. Ebbe N. Bak a,*, Kaloyan Zafirov aJonathan P. Merrison b, Svend J. c, et al.,(2017). Production of reactive oxygen species from abraded silicates. Implications for the reactivity of the Martian soil Earth and Planetary Science Letters 473:pp.113-121.

[11] E.Stojanović, V. Ristić, D. Travis .Mcmaster \& Z.Milanović.(2017). Effect of Plyometric Training on Vertical jump Performance in Female Athletes: PubMed.Gov. A Systematic Review and Meta- Analysis/ Sports Medicine.Vol. 47.Nr 5. Pp 975-986,.

[12] Christopher.J. Simez, Carries.A. Dugan , and William P Ebben.(2005). Journal of Strength and Conditioning Research, Vol.19(3), pp.495 - 504.

[13] Bobbert, MF.,Van Soest, AJ. (1994). Effects of muscle strengthening on vertical jump height: a simulation study. Medicine Science Sports Exercise,;Vol 26(8), pp.1012-1020.

[14] A Lees , E Fahmi. (1994). Optimal drop heights for plyometric training. Journal Ergonomics. Online Vol.37 (1), pp.141-148.

[15] Walsh, Arampatzis, Schade, \& Bruggemann; (2004).Effect of DJ starting height and contact time Journal of Strength and Conditioning Research Vol.18(3),pp.561-566.

[16] Bosco ,C., Komi .PV.(1979). Potentiation of the mechanical behaviour of the human skeletal muscle through stretching. Acta Physiologica Scandinavica,; Vol.106: pp.467-472.

[17] G.Markovic,P.Mikulic. (2010). NeuroMusculoskeletal and Performance Adaptations to Lower-Extremity Plyometric Training. Journal Sports Medicine. Vol. 40(10):pp.859- 895.

[18] Komi, P.V.,\&C. Bosco. (1978) .Utilization of stored elastic energy in leg extensor muscles by men and women. Med. Sci. Sports 10: pp.261265. 